\title{
Mode and food habits of athletes of Kazakhstan
}

\author{
Yerzhanova Y. ${ }^{1 \mathrm{ABCD}}$, Sabyrbek Z. ${ }^{\mathrm{ABCD}}$, Dilmachambetov E. ${ }^{1 \mathrm{CDE}}$, Madijeva G. ${ }^{1 \mathrm{BCE}}$, Milašius K. ${ }^{2 \mathrm{ABCD}}$ \\ ${ }^{1}$ Al-Farabi Kazakh National University, Almaty, Kazakhstan \\ ${ }^{2}$ Vytaytas Magnus University, Kaunas, Lithuania
}

Authors' Contribution: A - Study design; B - Data collection; C - Statistical analysis; D - Manuscript Preparation; E - Funds Collection.

\begin{abstract}
Purpose: $\quad$ The aim of the study was to evaluate the mode and the eating habits of some sports athletes as well as to find out the sources of received knowledge about nutrition athletes.

Material: In the evaluation of actual nutrition in 2017, 60 participants took part, including 15 volleyball players of the Burevestnik team, 15 judo wrestlers of the national team of Kazakhstan, 15 wrestlers of the club team and 15 triathletes of the national team of Kazakhstan. To study data on the regime and eating habits, a valid questionnaire was used, directly interviewing each researcher. The statistical analysis of the survey data was carried out, the percentage distribution of responses on the questionnaire was calculated. For the analysis of categorical data $x 2$ test (chi-square) have been applied.

Results: $\quad$ The results of the study have shown that Kazakhstan sportsmen diet is not optimal, not enough of the studied athletes eat 4 or more times a day. $22.7 \%$ of the respondents are snacking not enough - only once per day, and $11.7 \%$ of the respondents do not snack at all. More than half of the subjects $(52 \%)$ regularly eats every day at the same time, while $48 \%$ - not always eat regularly.

Conclusions: The main criterion for the selection of food is taste, paying too little attention to the specificity of sport and on a special diet. Basic information about nutrition investigated Kazakh athletes receive from coaches and family members, and the share of doctors and nutritionists have to too small impact here. Public information systems are relatively ineffective.

Keywords: athletes, diet, eating habits, food, knowledge about nutrition.
\end{abstract}

\section{Introduction}

The organization of rational nutrition of athletes implies the existence of a certain regime, including the distribution of meals throughout the day, the number of meals and must be strictly coordinated with the training process $[1,2]$. The distribution of the food ration for a day depends on what time of day the basic physical load is being performed, what is its frequency and nature [3, 4]. The optimal distribution of food consumed during the day is also important. For example, the optimal diet athlete, calculated consumption of $5500 \mathrm{kcal}$ (Sports Endurance with two training sessions), with 5-course meal on the distribution of caloric intake as follows: first breakfast $10 \%$ of the total number kilocalories, morning training, second breakfast - $25 \%$, lunch - $35 \%$, afternoon snack $5 \%$, evening training, dinner $-25 \%$ of the total volume of kilocalories $[2,5,6]$. There is no doubt that, by eating 4-5 times a day, eating between meals, you cannot only avoid the disorder of the digestive tract, but also provide the body with essential nutrients. Many scientists [6-9] believe that eating habits to determine the health of 25 $30 \%$. The scientific literature emphasizes that it is the way of life, good hygiene, eating habits, working conditions, physical activity and rest that have a major impact on health [10].

The appropriate diet regimen determines the adaptation of the body to physical activity and helps achieve the highest sporting results $[11,12]$. Due to the heavy workload, lack of time, athletes nutrition habits do not always comply with the recommendations of a balanced (c) Yerzhanova Y., Sabyrbek Z., Dilmachambetov E., Madijeva G., Milašius K., 2018

doi:10.15561/18189172.2018.0608 diet [13]. One of the factors that are not conducive to compliance with the rules of rational nutrition of athletes - the lack of knowledge about nutrition [14-16]. Although athletes learn about nutrition from number of information sources, the most important sources of nutrition knowledge are coaches, close friends, radio and television broadcasts [17]. On the other hand, as some researchers note, the data presented do not always correspond to the truth, which implies that athletes do not always receive the right information about $[16,18,19]$. Therefore, although the flow of scientific information about nutrition is sufficiently large, the athletes do not have the right information about nutrition, they do not understand the basic concepts of nutrition, so in the training process it is necessary to prepare and implement special educational programs that provide basic knowledge about nutrition [20-22].

In Kazakhstan, the regime and the eating habits of athletes still insufficiently investigated, uncertain principal criteria governing regime and eating habits; the value of the acquired knowledge on the formation of habits of athletes of different sports has to be investigated.

It has defined the aim of our research: to evaluate the mode and the eating habits of some sports athletes as well as to find out the sources of the athletes received nutritional knowledge.

\section{Material and Methods}

Participants.

In the process of evaluation of actual nutrition in 2017, 60 athletes were studied, including 15 volleyball players of the Burevestnik team in Almaty, playing at the 
national championship, 15 judo wrestlers of the national team of Kazakhstan, 15 wrestlers of the club team and 15 triathletes of the national team of Kazakhstan. The age of volleyball players was 19-22 years, their height averaged $188.0 \pm 8.38 \mathrm{~cm}$, body weight - on the average $78.11 \pm 7.68 \mathrm{~kg}$, BMI averaged 22.1. The age of judoists was 20-28 years old, their average height was $174.3 \pm 8.3$ $\mathrm{cm}$, body weight - on the average $78.0 \pm 18.9 \mathrm{~kg}$, BMI was on average 25.74 . The age of judoists of the club team was from 17 to 21 years, their average height was $171.9 \pm 6.0$ $\mathrm{cm}$, body weight - 71.0 $\pm 16.1 \mathrm{~kg}$, BMI - on average 24.07. The age of the triathletes studied was 21-30 years old, their average height was $180.0 \pm 7.2 \mathrm{~cm}$, body weight - on average $65.5 \pm 7.1 \mathrm{~kg}$, body mass index (BMI) averaged 20.2.

\section{Research Design.}

Aiming to investigate data on the regime and eating habits, validated questionnaire [23] had been applied for direct examination of every testee. The questionnaire included questions about sociodemographic data of athletes, eating habits (product selection criteria), frequency of consumption of individual foods, regularity of nutrition, information sources on nutrition. The length of the questionnaire was not limited and averaged 30-45 minutes. The survey was carried out during training camps at the place of their conduct. For the study, permission was obtained from the ethics committee of the Al-Farabi Kazakh National University with voluntary consent to participate in the research. Confidentiality of the research data was observed.

Statistical analysis. Statistical analysis of the survey data was carried out using the "Statistical Package for Social Sciences" program (SPSS, version 16). Analyzing the data was calculated the percentage distribution of the responses on the questionnaire. For analysis of categorical data applied $\chi^{2}$ test (chi-square). Statistical significance was at $\mathrm{p}$ less than or equal to 0.05 .

\section{Results}

The essence of rational and balanced nutrition is to satisfy increased demand of the body when performing physical exertion. Evaluating opinion of respondents on their rational and balanced nutrition, in general can be noted that $60 \%$ participants consider their nutrition as such and $28.3 \%$ found it difficult to answer. $93.3 \%$ judoists of national team consider their nutrition rational and balanced, $60 \%$ triathletes found it difficult to respond positively (Table 1).

Athletes are obliged to observe the correct diet, eating 3-4 times a day at the same time, and 2-3 times a snack between meals. Analyzing the answers Kazakh athletes to the question "How many times a day eat" the majority of respondents $(78 \%)$ said that the day they eat three times, twice $-12 \%$, four times or more $-10 \%$ of the study (Figure 1).

Among all investigated, $60 \%$ of volleyball players, $100 \%$ judo national team, $80 \%$ of the club's judo team and $73.3 \%$ of triathletes eat three times a day. This quantity corresponds to recommended eating rate $(\chi 2=14.800, p$ $=0.01$ ).

Analyzing the frequency of snacking, it was found that $33.3 \%$ of our study Kazakh athletes snack twice, and $18.3 \%$ - three times, $10 \%$ - four times and more. It should be noted that the most common snacking among triathletes, including snacking twice (40\%), three times $40 \%$, four times or more - $10 \%$. Not enough, only once snacked $21.7 \%$ of respondents, and not snacked $-16.7 \%$ of respondents (Table 2).

By analyzing the respondents' answers to the question "Do you eat at the same time", it turned out that every day on a regular basis at the same time, eat $52 \%$ of the study, 3-5 times a week - 25\% 1-2 times a week - $18 \%$ and $5 \%$ of the study direct supply is not regular (Fig. 2).

Statistically significant are the responses of judoists of both groups who believe that they eat at the same time every day $\left(\chi 2=19,200, p=0,00\right.$ and $\chi^{2}=18,867$, $\mathrm{p}=0,00$ ), while the answers of volleyball players and triathlonists did not reveal a significant difference in choosing a constant time of eating.

When possible, choose a few answers, most of the subjects (78.3\%), the main criterion by which they choose foods are palatability. Opportunity to improve the health of selection of certain products considered $46.7 \%$ of athletes we investigated. Relatively rarely athletes pay attention to the choice of food products for the specificity of sports - only $8.4 \%$ of those surveyed and on the possibility of a special diet (6.7\%) (Table 3).

Evaluating the athletes' answers to the question "Where do you get knowledge about nutrition?" Was determined the source of information about nutrition. According to our study $36.7 \%$ of respondents receive information about nutrition from the coach, $20.0 \%$ - from

Table 1. The Results of the Participant's Opinion About Quality of their Nutrition

\begin{tabular}{lllllc}
\hline Criteria & $\begin{array}{l}\text { Volleyball } \\
\text { players } \\
\mathbf{n = 1 5}\end{array}$ & $\begin{array}{l}\text { National team } \\
\text { judoists } \\
\mathbf{n}=\mathbf{1 5}\end{array}$ & $\begin{array}{l}\text { Judoka club } \\
\text { team } \\
\mathbf{n}=\mathbf{1 5}\end{array}$ & $\begin{array}{l}\text { Triathletes } \\
\mathbf{n}=\mathbf{1 5}\end{array}$ & $\bar{X}$ \\
\hline Rational and balanced & 53.3 & 93.3 & 66.7 & 26.7 & 60.0 \\
Not rational and balanced & 13.3 & $\begin{array}{l}\chi^{2}=11.267 \\
p<0.01\end{array}$ & & & \\
Difficult to answer & 33.4 & 6.7 & 20.0 & 13.3 & 11.7 \\
\hline
\end{tabular}




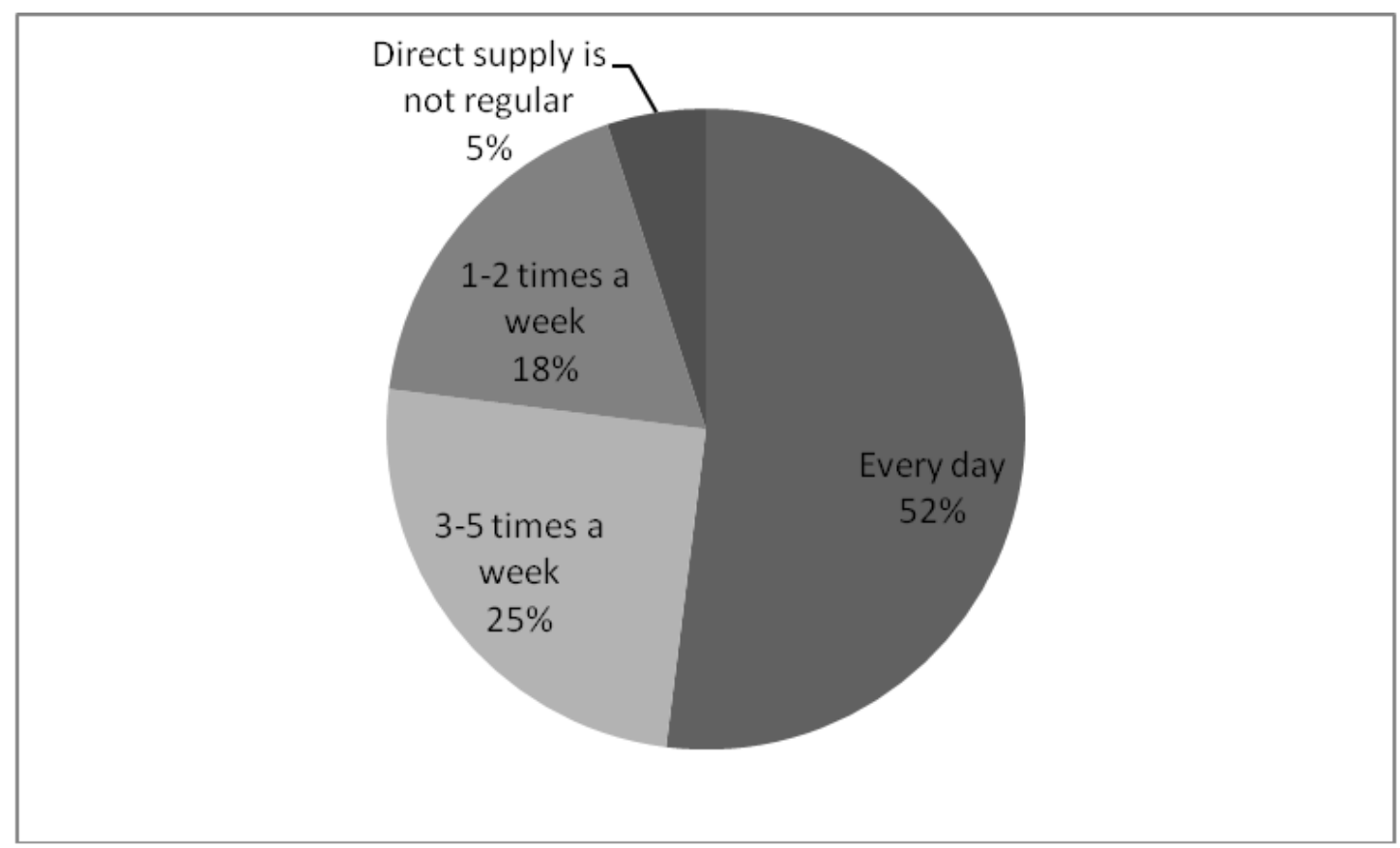

Figure 1. The results of the answer to the question "How many times do you eat per day?"

Table 2. Percentage Distribution of Athletes According to the Number of Snacks Depending on the Sport

\begin{tabular}{|c|c|c|c|c|c|}
\hline $\begin{array}{l}\text { Groups of } \\
\text { athletes }\end{array}$ & Do not snack \% & Once a day \% & $\begin{array}{l}\text { Twice } \\
\text { a day \% }\end{array}$ & $\begin{array}{l}\text { Three times } \\
\text { a day } \%\end{array}$ & $\begin{array}{l}\text { Four times } \\
\text { and more per } \\
\text { day } \%\end{array}$ \\
\hline $\begin{array}{l}\text { Volleyball } \\
\text { players }\end{array}$ & 13.3 & $\begin{array}{l}46.7 \\
\chi^{2}=4.467 p=0.30\end{array}$ & 26.7 & 0 & 13.3 \\
\hline $\begin{array}{l}\text { National team } \\
\text { judoists }\end{array}$ & $\begin{array}{l}40 \\
\chi^{2}=4.000 \\
p=0.35\end{array}$ & 20 & 13.3 & 13.3 & 13.3 \\
\hline $\begin{array}{l}\text { Judoists of the } \\
\text { club team }\end{array}$ & 13.3 & 13.3 & $\begin{array}{l}53.3 \\
\chi^{2}=6.600 \\
p=0.25\end{array}$ & 20.0 & 0 \\
\hline Triathletes & 0 & 6.7 & $\begin{array}{l}40 \\
\chi^{2}=5.533 p=0.15\end{array}$ & 40 & 13.3 \\
\hline $\bar{X}$ & 16.7 & 21.7 & 33.3 & 18.3 & 10.0 \\
\hline
\end{tabular}

family members, $16.7 \%$ - from other sources, at least - by a nutritionist (10.0\%) and doctors (8.3\%) (Table 4$)$.

It should be noted that the level of knowledge essentially determines a more healthy, appropriate rational nutrition.

\section{Discussion}

Athletes eat not efficiently 3 times a day, because they do not support the need for the concentration of glucose in the blood, and during the meal they consume large amounts of food. Many authors investigating diet believe that athletes should eat 4-5 times at the same time [24$26]$. According to our study, only $10 \%$ of respondents eat 4-5 times a day, whereas according to J. Lee et al. [25] 60-70\%. Z. Szygula et al [6] assessing the diet of Polish athletes, found that, $55 \%$ of athletes eat $4-5$ times a day. The same authors have shown that $28 \%$ of the studied triathletes 5 times a day, and $50 \%$ of triathletes eat 4 times a day. Incorrect diet was detected during the examination of basketball players and football players. Most of these athletes (48\%) eat only 3 times, 34\% - 4 times, and only $13 \%$ - 5 times a day [27].

Along with the basic eating habits it is important for athletes to snack throughout the day. As the authors point out $[28,29]$, the amount of snacking should be $2-3$ times a day. These recommendations are followed by $59 \%$ of the athletes we surveyed.

$78.3 \%$ of the Kazakhstan athletes we studied choose food products mainly guided by taste, paying little attention to the specifics of the sport and a special diet. The positive thing is that by choosing the products they pay attention to their impact on improving health. This opinion is shared by $46.7 \%$ of respondents. Some authors, aiming to improve the level of knowledge 


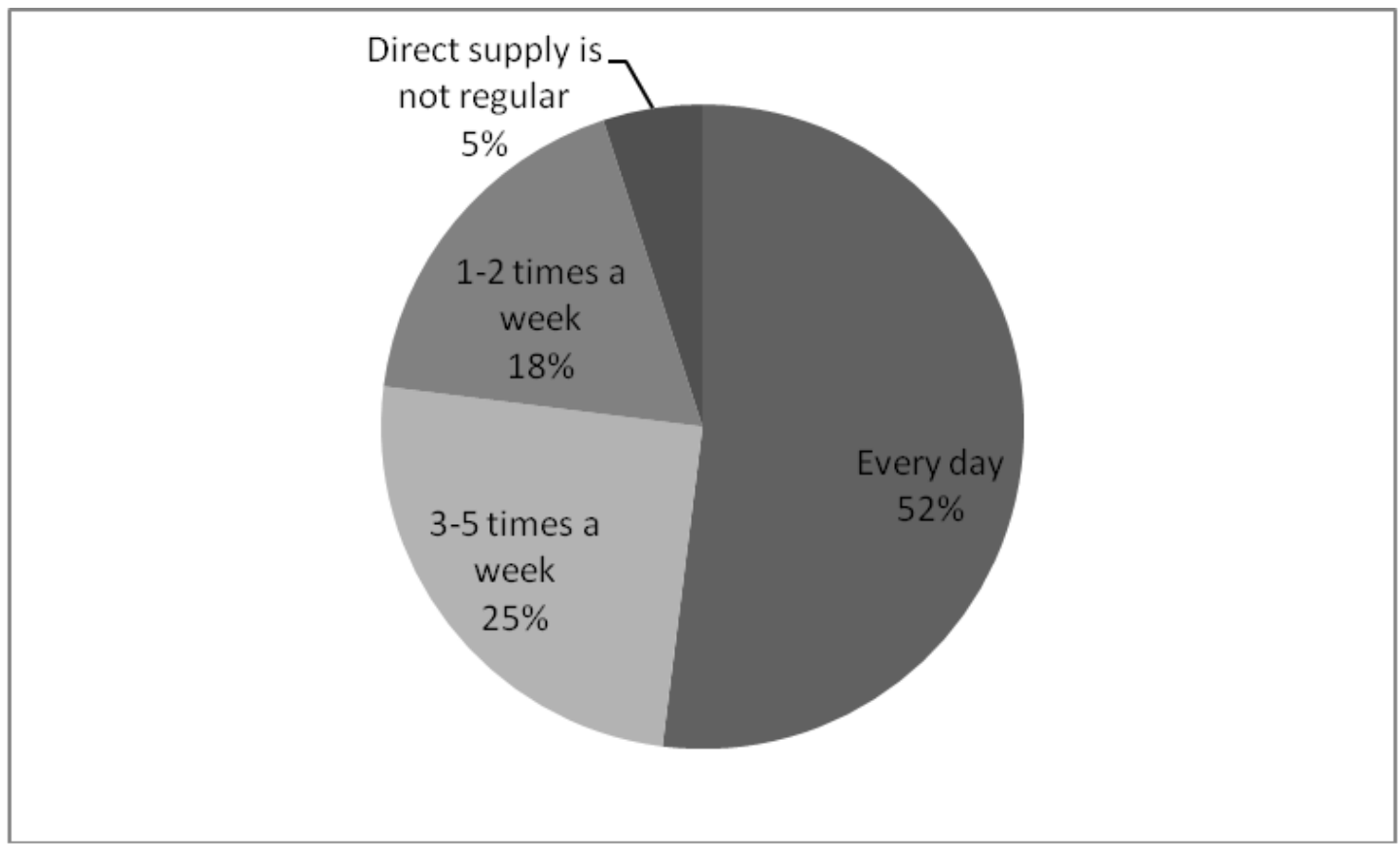

Figure 2. The results of the answer to the question "Do you eat at the same time?"

Table 3. Percentage Distribution of the Main Criteria by Which Athletes are Selected Products

\begin{tabular}{llllll}
\hline Criteria & $\begin{array}{l}\text { Volleyball } \\
\text { players } \mathbf{n = 1 5}\end{array}$ & $\begin{array}{l}\text { National team } \\
\text { judoists } \mathbf{n = 1 5}\end{array}$ & $\begin{array}{l}\text { Judoka club } \\
\text { team } \mathbf{n = 1 5}\end{array}$ & $\begin{array}{l}\text { Triathletes } \\
\mathbf{n = 1 5}\end{array}$ & $\bar{X}$ \\
\hline Improving health & 73.3 & 20.0 & 60.0 & 33.3 & 46.7 \\
Special Diet & 13.3 & 6.7 & 0 & 6.7 & 6.7 \\
Price & 26.6 & 0 & 13.3 & 6.7 & 11.7 \\
& 66.7 & 93.3 & 80.0 & 73.3 & 73.3 \\
Taste qualities & & $\chi^{2}=11.267$ & $\chi^{2}=11.267$ & $\chi^{2}=8.067$ \\
& & $p<0.01$ & $p<0.01$ & $p=0.06$ & \\
Influence of family members & 0 & 6.7 & 6.7 & 0 & 3.4 \\
The influence of the coach & 6.7 & 20.0 & 26.7 & 13.3 & 16.7 \\
Specificity of the sport & 26.7 & 0 & 0 & 6.7 & 8.4 \\
\hline
\end{tabular}

Table 4. Percentage Distribution Source of the Received Information About Nutrition

\begin{tabular}{llllll}
\hline Information sources & $\begin{array}{l}\text { Volleyball } \\
\text { players } \mathbf{n = 1 5}\end{array}$ & $\begin{array}{l}\text { National team } \\
\text { judoists } \\
\mathbf{n = 1 5}\end{array}$ & $\begin{array}{l}\text { Judoka club } \\
\text { team } \\
\mathbf{n}=\mathbf{1 5}\end{array}$ & $\begin{array}{l}\text { Triathletes } \\
\mathbf{n}=\mathbf{1 5}\end{array}$ & $\bar{X}$ \\
\hline From TV and radio & 13.3 & 0 & 0 & 6.7 & 5.0 \\
From doctors & 13.3 & 13.3 & 0 & 6.7 & 8.3 \\
Reading popular literature & 6.7 & 0 & 0 & 0 & 1.7 \\
From a nutritionist & 6.7 & 20.0 & 0 & 13.3 & 10.0 \\
& 40.0 & 20.0 & 53.4 & 33.3 & 36.7 \\
From the coacher & & & $\chi 2=6.600$ & & \\
& & 0 & $0=0.25$ & & 1.7 \\
From friends & 6.7 & 0.7 & 0 & 0.7 & 20.0 \\
From family members & 13.3 & 26.7 & 33.3 & 6.7 & 16.7 \\
From other sources & 0 & 20.0 & 13.3 & 33.3 & \\
\hline
\end{tabular}


offered to introduce education program [20-22], having in mind that between the athlete and the coach there is a close relationship. In this regard, the ongoing educational programs that provide information on nutrition should be targeted not only at athletes, but also at coaches, since athletes' nutritional mistakes are based on insufficient coverage of the recommendations of rational nutrition.

According to our research, the main source of information is the coach. On the other hand, knowledge of nutrition can be determined by socio-demographic factors: gender, age, specificity of the sport, education [8]. Authors who have studied the level of knowledge, determined that it depends on the athlete's education $[6$, 30]. However, there is evidence that many athletes do not have enough knowledge about rational nutrition, proper $\operatorname{diet}[15,17,20,23,30,31]$. D. Dunn et al. [6] note that the main problem that today confronts the youth of American colleges and universities is the easy accessibility of fast foods or easily cooked foods. Current research shows that as the knowledge of athletes increases, the quality of food consumption improves [32]. In the scientific literature it is noted that qualified knowledge about nutrition can improve the nutritional status. B. Jacobson et al. [16], L. Zawila et al. [20], M. Jessri et al [31] note that athletes receive information about nutrition from public audiovisual aids, the Internet, from popular literature, friends, family members. L. Birch., J. Fisher [33] focuses on the role of parents in feeding athletes, especially the young, determining what, when and how much they should eat excluding their self-control. However, athletes receive the greatest amount of knowledge about nutrition from coaches $[19,26]$. C. Juzwiak, F. Ancona-Lopez [34] note that specific dietary advice on nutrition to Brazilian athletes before and after the competitions recommended respectively - 93 and $46 \%$ of the interviewed trainers. No exception and our respondents - Kazakhstani athletes, $36.7 \%$ had a basic knowledge of nutrition is obtained from the coach. In this regard, the coach must possess not only the methodology of training, but a sufficient number of physiological knowledge. On the other hand, the results of some researchers show that the level of knowledge of coaches about nutrition is not sufficient [31, 35, 36], and information sources (TV, radio programs, popular literature , friends, family members) do not always provide qualified nutrition information to athletes $[8,16]$.

\section{Conclusions}

1. An insufficient amount of researched kazakh athletes consider their nutrition rational and balanced.

2. The nutrition regime of Kazakhstani athletes is not optimal, not enough of the athletes under study eat 4 or more times a day. $22.7 \%$ of the respondents are snacking not enough - only once per day, and $11.7 \%$ of the respondents do not snack at all.

3. More than half of the subjects (52\%) regularly eat every day at the same time, while $48 \%$ - not always eat regularly. The main criterion for the selection of food is taste, thus paying too little attention to the specificity of sport and on a special diet.

4. Basic information about nutrition investigated Kazakh athletes receive from coaches and family members, the share of doctors and nutritionists have to too small an amount it. Public information systems are relatively ineffective.

\section{Conflicts of Interest}

There isn't any conflict of interest to be declared regarding the manuscript.

\section{References}

1. Czaja J, Lebiedzińska A, Szefer P. Nutritional habits and diet supplementation of Polish middle and long distance representative runners (years 2004-2005). Roczniki Panstwowego Zakladu Higieny, 2008; 59(1): 67-74.

2. Korosteleva M, Nikityuk D, Volkova L. Peculiarities of nutrition organization of young athletes. Problems of Nutrition, 2013; 82(6): 41-48. (in Russian)

3. Tutelyan V, Gapparov MG, Baturin A, Nikityuk D, Ordzhonikidze Z, Pozdnyakov A. About the role of nutrition individualization in the sport of higher achievements. Problems of Nutrition, 2011; 80(5): 78-83. (in Russian)

4. Mustafin S K. Nutrition athlete. Almaty: Bastau Publishing; 2012, 228 p. (in Russian)

5. Sánchez-Benito JL, León Izard P. Estudio de los hábitos alimentarios de jóvenes deportistas (Study of dietary habits of young sportsmen). Nutricion Hospitalaria, 2008; 23(6): 622-623.

6. Szygula Z., Kazimierczak K., Golec E, SchlegelZawadzka M. Dietary habits among young triathlonists as a result of proecological style of life-preliminary study. Medicina Sportiva, 2009; 13(3): 185 - 188. https://doi.org/10.2478/v10036-009-0030-5

7. Teshima K, Imamura H, Yoshimura Y, Nishimura S, Miyamoto N, Yamauchi Y, Hori H, Moriwaki C, Shirota T. Nutrient

intake of highly competitive male and female collegiate karate players. Journal of Physiological Anthropology and Applied Human Science, 2002; 21(4): 205-211. https://doi.org/10.2114/jpa.21.205

8. Nazni P, Vimala S. Nutrition knovvledge, attitude and practice of college sportsmen. Asian Journal of Sports Medicine, 2010; 1(2): 93-100. https://doi.org/10.5812/asjsm.34866

9. Ubeda N, Palacios Gil-Antunano N, Montalvo Zenarruzabeitia Z, Garcia Juan B, Garcia A, Iglesias-Gutierrez E. Food habits and body composition of Spanish elite athletes in combat sports. Nutrición Hospitalaria, 2010; 25 (3): 414-421.

10.Szpakow A, Nawojczyk A, Szpakow N, Kleszzewska F, Jaszczuk A, Dolinska C, Cis K. Ocena żywienia i zwyczajów żywieniowych młodzieży akademickiej $\mathrm{z}$ Grodna i Białegostoku. Reabilitacja w Praktyce, 2008; (2): 17-22.

11.American College of Sports Medicine, American Dietetic Association, and Dietitians of Canada: Nutrition and Athletic Performance (joint position statement). Medicine and Science in Sports and Exercise, 2009; (41): 709-731. https://doi.org/10.1249/MSS.0000000000000852

12.Boguszewski D, Adamczyk, J, Buda M, Białoszewski D. The estimation of health-related behaviours of male judokas. JournalofCombatSportsandMartialArts, 2013;4(2):179-184. https://doi.org/10.5604/20815735.1090675 
13.Kouloutbani K, Eftsathiou T, Stergioulas A. Eating disorders in the world of sport: the experiences of rhythmic gymnasts. Journal of Biology of Exercise, 2012; 8(2): 19-31. https://doi.org/10.4127/jbe.2011.0057

14.Wyka J, Zechałko-Czajkowska A. Nutritional knowlegde, lifestyle and food groups intake in the group of the first year students of Agricultural University in Wroclaw. Roczniki Panstwowego Zakladu Higieny, 2006; 57(4): 381-388.

15.Malinauskas BM, Overton RF, Cucchiara AJ, Carpenter AB, Corbett AB. Summer league college baseball players: Do dietary intake and barriers to eating healthy differ between game and non-game days? Sport Management and Related Topics Journal, 2007; 3(2): 23-34.

16.Jessri M, Jessri M, RashidKhani B, Zinn C. Evaluation of Iranian college athletes sport nutrition knowledge. International Journal of Sport Nutrition and Exercise Metabolism, 2010; (20): 257-263. https://doi.org/10.1123/ijsnem.20.3.257

17.Rosenbloom CA, Jonnalagadda SS, Skinner R. Nutrition knowledge of collegiate athletes in a Division I National Collegiate Athletic Association institution. Journal of the American Dietetic Association, 2002; (103): 418-421. https://doi.org/10.1016/S0002-8223(02)90098-2

18. Mitchell C, Nutritional knowledge of high school athletes. WestVirginia University school of Physical Education Thesis 2004; 3-14.

19.Gacek M. Knowledge and nutritional behaviours among youth practising sports at school of sports championship in Cracov. Roczniki Panstwowego Zakladu Higieny, 2007; 58(4): 641-649.

20.Zawila LG, Steib CM, Hoogenboom B. The female collegiate cross-country runner: Nutritional knowledge and attitudes. Journal of Athletic Training, 2003; 38(1): 67-74.

21.Froiland K, Koszewski W, Hingst J, Kopecky L. Nutritional supplement use among college athletes and their sources of information. International Journal of Sport Nutrition and Exercise Metabolism, 2004; (14): 104-120. https://doi.org/10.1123/ijsnem.14.1.104

22.Nowacka E, Leszczyńska T, Kopeć A, Hojka D. Nutritional behavior of Polish canoeist's athletes: The interest of nutritional education. Science and Sports, 2016; 31(4): 79. https://doi.org/10.1016/j.scispo.2016.04.002

23.Baranauskas M. Assessment of actual nutrition and dietary habits of athletes during the 2008-2012 Olympic period. Doctoral dissertation, Biomedical Sciences, Public Health, Vilnius University; 2012, 256 p.

24.Hinton PS, Sanford TC, Davidson MM, Yakushko OF, Beck NC. Nutrient intakes and dietary behaviors of male and female collegiate athletes. International Journal of Sport
Nutrition and Exercise Metabolism, 2004; (14): 389-404. https://doi.org/10.1123/ijsnem.14.4.389

25.Lee JS, Kim MH, Bae Y, Choe YH, Sung CJ. A study of dietary habits, nutrition intake status and serum copper and zinc concentrations of adolescent athletes. Korean Journal of Nutrition, 2005; 38(6): 465-474.

26.Dunn D, Turner LW, Denny G. Nutrition knowledge and attitudes of college athletes. The Sport Journal, 2007; 10(4): 45-53.

27.PasalicA, JusupovicF, Obradovic Z, MahmutovicJ.Nutritional awareness and habits of Premier league sportsmen in the SarajevoCanton.JournalofHealthSciences, 2012;2(1):54-60. https://doi.org/10.17532/jhsci.2012.64

28. Rossi L, Goya R, Matayoshi M, Pereira C, Bernardo da Silva J. Nutritional evaluation of taekwondo athletes. Brazilian Journal of Biochemistry, 2009; 3(2): 159-166.

29.Quintana SM, Garcia A, Torres G, Pastor G. Dietary habits and nutritional intervention in elite Spanish athletes. World Congress on Science in Athletics. Barcelona; 2010.

30.Rash CL, Malinauskas BM, Duffrin MW, Barber-Heidal K, Overton RF. Nutrition-related knowledge, attitude, and dietary intake of college track athletes. The Sport Journal, 2008; 11(4): 48-56.

31.Jacobson BH, Sobonya C, Ransone J. Nutrition practices and knowledge of college varsity athletes: A follow-up. Journal of Strength and Conditioning Research, 2001; 15(1): 63-68. https://doi.org/10.1519/00124278-200102000-00011

32.Kunkel ME, Bell LB, Luccia BH. Peer nutrition education program to improve nutrition knowledge of female collegiate athletes. Journal of Nutrition Education, 33(2): 114-115. https://doi.org/10.1016/S1499-4046(06)60175-9

33.Birch L, Fisher J. Development of eating behaviors among children and adolescents. Pediatrics, 1998; 101 (3 Pt 2): 539-549.

34.Juzwiak C, Ancona-Lopez F. Evaluation of nutrition knowledge and dietary recommendations by coaches of adolescent Brazilian athletes. International Journal of Sport Nutrition and Exercise Metabolism, 2004; 14(2): 222-235. https://doi.org/10.1123/ijsnem.14.2.222

35.Jazayeri M, Amani R. Nutritional knowledge and practices of bodybuilding trainers in Ahwaz, Iran. Pakistan. Journal of Nutrition, 2004; 3(4): 228-231. https://doi.org/10.3923/pjn.2004.228.231

36.Torres-Mcgehee TM, Pritchett KL, Zippel D, Minton, DM, Cellamare A, Sibilia M. Sports nutrition knowledge among collegiate athletes, coaches, athletic trainers, and strength and conditioning specialists Journal of Athletic Training, 2012; 47(2): 205-211. https://doi.org/10.4085/1062-6050-47.2.205 


\section{Information about the authors:}

Yerzhanova Y.; http://orcid.org/0000-0003-1304-1824; Eldana_777@mail.ru; Al-Farabi Kazakh National University, 71 al-Farabi Ave., Almaty, 050040, Kazakhstan.

Sabyrbek Z.; http://orcid.org/0000-0001-5014-5441; zhanna.sabyrbek@kaznu.kz; Al-Farabi Kazakh National University, 71 al-Farabi Ave., Almaty, 050040, Kazakhstan.

Dilmachambetov E.; http://orcid.org/0000-0001-7609-7927; Ermek.Dilmakhanbetov@kaznu.kz; Al-Farabi Kazakh National University, 71 al-Farabi Ave., Almaty, 050040, Kazakhstan.

Madiyeva G.; http://orcid.org/0000-0002-8409-3838; Eldana_777@mail.ru; Al-Farabi Kazakh National University, 71 al-Farabi Ave., Almaty, 050040, Kazakhstan.

Milašius K.; (Corresponding author); http://orcid.org/0000-0002-1109-7421; kazys.milasius@leu.It; Vytautas Magnus University, K. Donelaičio st. 58 , Kaunas, 44248 , Lithuania.

Cite this article as: Yerzhanova Y., Sabyrbek Z., Dilmachambetov E., Madijeva G., Milašius K. Mode and food habits of athletes of Kazakhstan. Pedagogics, psychology, medical-biological problems of physical training and sports, 2018;22(6):328-334. https:// doi.org/10.15561/18189172.2018.0608

The electronic version of this article is the complete one and can be found online at: http://www.sportpedagogy.org.ua/index.php/PPS/issue/archive

This is an Open Access article distributed under the terms of the Creative Commons Attribution License, which permits unrestricted use, distribution, and reproduction in any medium, provided the original work is properly cited (http://creativecommons.org/licenses/by/4.0/deed.en).

Received: 18.08.2018

Accepted: 15.09.2018; Published: 22.12.2018 